American Journal of Pharmaceutical Education 2019; 83 (4) Article 7218.

\title{
THEME ISSUE
}

\section{Cultural Sensitivity and Global Pharmacy Engagement in Latin America: Argentina, Brazil, Ecuador, Guatemala, and Mexico}

\author{
Sally L. Haack, PharmD, ${ }^{\mathrm{a}}$ Inbal Mazar, PhD, ${ }^{\mathrm{a}}$ Erin M. Carter, MS, ${ }^{\mathrm{a}}$ Joyce Addo-Atuah, PhD, MSc, BPharm, \\ Melody Ryan, PharmD, MPH, ${ }^{\mathrm{c}}$ Laura Leticia Salazar Preciado, PhD, ${ }^{\mathrm{d}}$ Luis Renee González Lucano, MD, PhD, \\ Aliz Lorena Barrera Ralda, MD $^{\text {a }}$ \\ ${ }^{a}$ Drake University, Des Moines, Iowa \\ b Touro College of Pharmacy, New York, New York \\ ${ }^{\mathrm{c}}$ University of Kentucky, Lexington, Kentucky \\ ${ }^{\mathrm{d}}$ Centro Universitario de Cutonalá, Universidad de Guadalajara, Mexico \\ e Tecnológico de Monterrey, Campus Guadalajara, Escuela de Medicina, Mexico
}

Submitted June 19, 2018; accepted November 6, 2018; published May 2019.

To establish and maintain successful global pharmaceutical and health care partnerships, pharmacists, pharmacy educators, and students should first learn more about the political, cultural, economic and health care dynamics that affect all of the parties involved in these arrangements. This paper explores Latin America within the context of transnational pharmacy and health-based engagement, including pharmacy-related concepts, health care and cultural considerations, behavioral health perspectives, and common misconceptions. Expert knowledge and experience were used to support and corroborate the existing literature about cultural dynamics of health. Recommendations are provided for how schools and colleges of pharmacy can enhance engagement in culturally sensitive partnerships within Latin America. Health-based profiles of Argentina, Brazil, Ecuador, Guatemala, and Mexico are presented to serve as models for establishing, enhancing, and maintaining partnerships across Latin America.

Keywords: culture, sensitivity, global, Latin, Argentina, Brazil, Ecuador, Guatemala, Mexico

\section{INTRODUCTION}

Schools and colleges of pharmacy in the United States have demonstrated an increased interest in global health. ${ }^{1-3}$ Three factors are driving this change: changes in higher education that emphasize globalization, increased visibility of global health care needs, and resource expansion resulting in increased opportunities for students and universities. ${ }^{4}$ Similar to students in other health professions, US pharmacy students are increasingly pursuing Latin American field experiences in part because of the proximity of the region to the United States and the reasonable travel costs. Little information is available in the pharmacy literature regarding how students should prepare to provide culturally appropriate care in these settings, despite the importance of having cultural sensitivity and humility.

Latin America consists of predominantly Spanishand Portuguese-speaking nations. These nations comprise nearly $13 \%$ of the earth's total land surface area and share similarities as a result of their history of colonization by

Corresponding Author: Sally L. Haack, Drake University, 2507 University Ave., Des Moines, IA 50311. Tel: 515-2481556. E-mail: sally.haack@drake.edu
Spain or Portugal. ${ }^{5}$ Mexico, Central and South America, and the Spanish-speaking Caribbean islands of Puerto Rico, Cuba, and the Dominican Republic make up Latin America (Table 1). There are differences between countries and even within countries with respect to the cultural beliefs, values and customs, languages, socioeconomic status, and education of the people. The examples provided in this paper may not be generalizable to all cultural groups and individuals in Latin America. The health aspects of several Latin American nations are discussed, with a particular focus on Argentina, Brazil, Ecuador, Guatemala, and Mexico (Figure 1 and Table 2). These North, Central, and South American nations were selected to demonstrate the cultural and linguistic diversity of the region and to provide comparisons in population, education, political stability, spending designated to health, and additional factors that influence national health outcomes. Although Spanish-speaking Caribbean countries are not the focus of this paper, some of the cultural considerations discussed can serve as a guide for further exploration of those countries. Information about Puerto Rico can be found within the Caribbean review in this themed issue. 
American Journal of Pharmaceutical Education 2019; 83 (4) Article 7218.

Table 1. Countries in Latin America Ranked by Population ${ }^{5}$

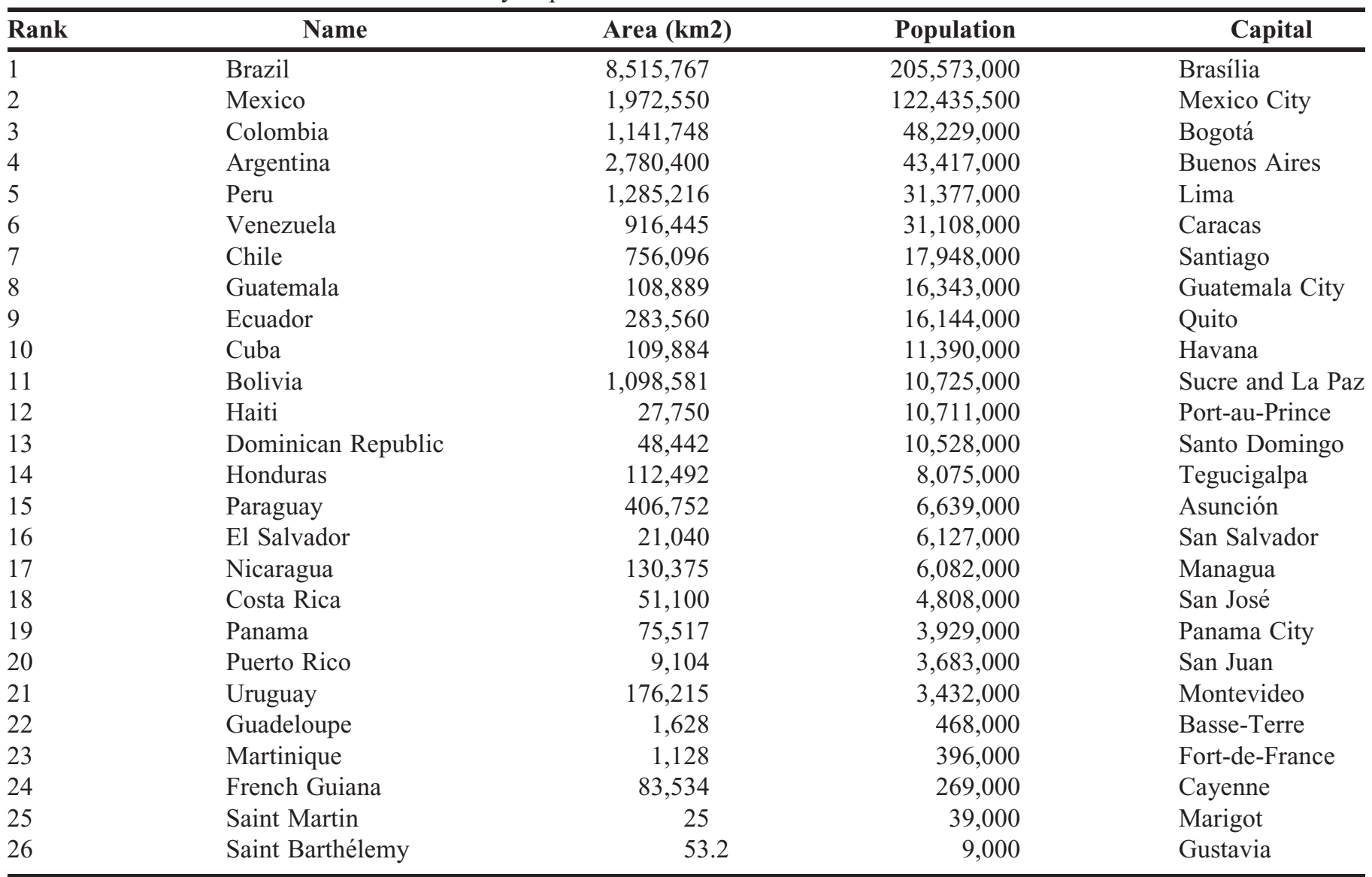

\section{METHODS}

This paper was developed using mixed methodologies which are described in the introduction article of this special theme. ${ }^{6}$ The expert knowledge and experience of individuals who have lived in Latin America as well as health care providers native to Latin America were used to support and corroborate the existing literature referenced in this paper.

\section{RESULTS}

\section{General Country Information}

Argentina. The Argentine Republic, more commonly called Argentina, covers a surface area of 2.8 million square kilometers, making it the eighth largest country in the world and the second largest country in South America after Brazil. ${ }^{7}$ Geographically, the country has a very diverse terrain, encompassing mountain ranges, lowlands, and plains, and equally diverse climatic conditions including tropical, subtropical, temperate, and subpolar areas. ${ }^{7}$ The population of Argentina is approximately 43.5 million. The population is $97 \%$ European, mostly of Spanish and Italian descent, and 3\% Mestizo (mixed Amerindian and white), Amerindian, and other nonwhite groups. ${ }^{7}$ Spanish is the official language and is spoken by the majority of the population. Most of the people live in urban areas and are Roman Catholic (92\%). ${ }^{7}$

Major industries in Argentina are in food processing, vehicle manufacturing, oil refinery, machinery and equipment, textiles, and chemical and petrochemical products. Soybeans and soybean derivatives, petroleum and gas, vehicles, corn, and wheat are the chief export commodities. ${ }^{7}$ Argentina, along with Brazil, Paraguay, and Uruguay are the original members of the South American trading block known as MERCOSUR (El Mercado Común del Sur) or the Southern Common Market. ${ }^{8}$

The Argentine Republic is a federation consisting of 23 largely independent provinces and the federal capital of Buenos Aires. The country had decades of political instability until it ushered in democratic rule in $1983 .{ }^{9}$

Brazil. Covering a surface area of 8.5 million square kilometers and $47 \%$ of South America, the Federative Republic of Brazil is a vast country and the largest in South America. ${ }^{10}$ Brazil has the fifth largest population in the world (207.6 million), 53.5\% of whom are employed or actively looking for a job, and $3.7 \%$ of whom are living below the poverty line. ${ }^{10}$ The official language 


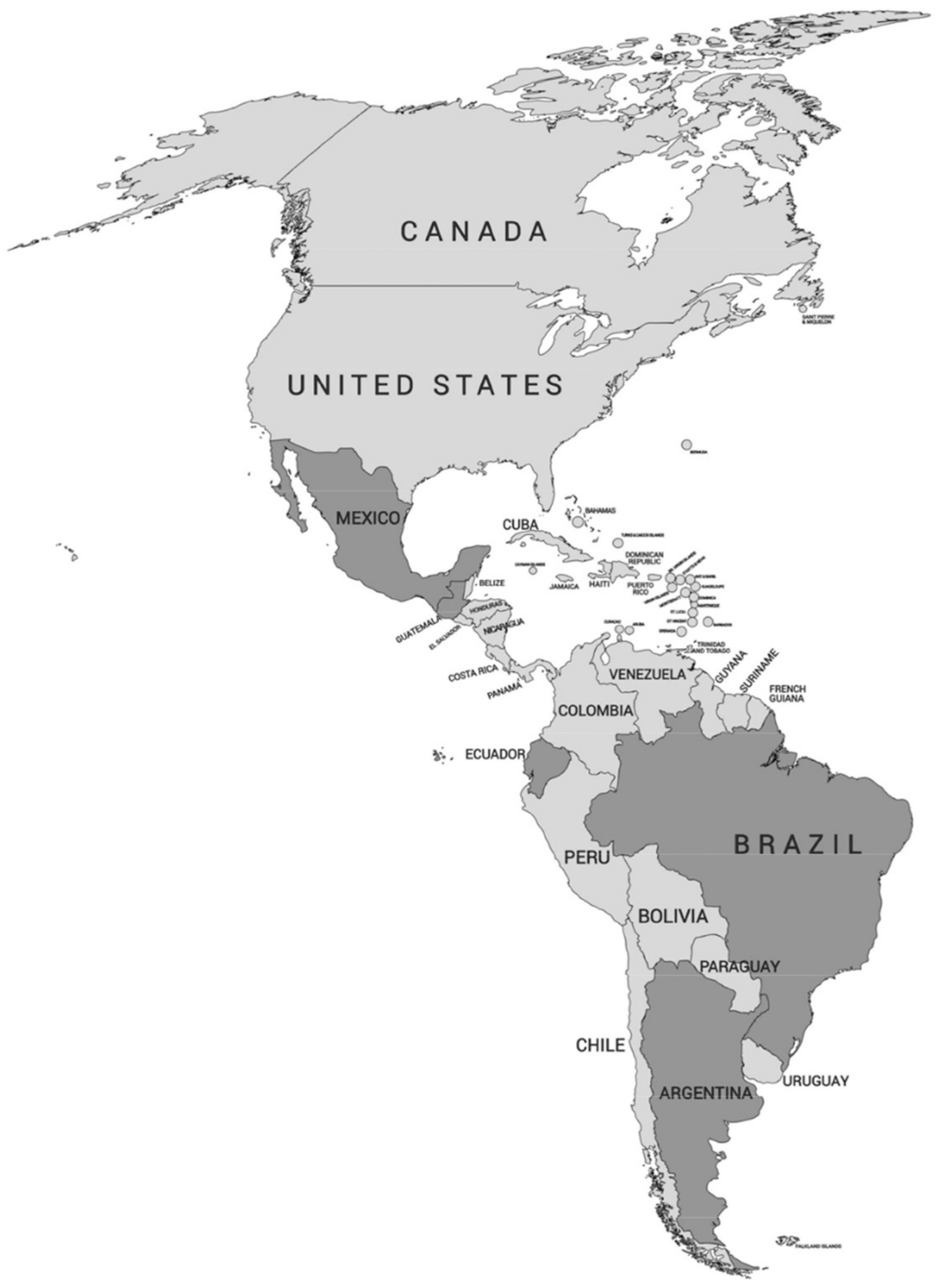

Created with mapchart.net 0

Figure 1. Map of Latin America

of Brazil is Portuguese and is spoken by $98 \%$ of the people, with German and indigenous languages making up the remaining $2 \%$. Brazil's population is very diverse, made up of $46.2 \%$ white, $45 \%$ multiracial, $7.9 \%$ black, and $0.8 \%$ Asian and indigenous groups. ${ }^{11}$ The majority of the population $(84.4 \%)$ are urban dwellers, but the indigenous people live in remote jungles and farms. The majority of the underserved, low-income, and marginalized people, mostly descendants of former slaves, live in the favelas (ghettos). ${ }^{11,12}$ 


\section{American Journal of Pharmaceutical Education 2019; 83 (4) Article 7218.}

Table 2. Comparison of Demographics and Other Variables Among Selected Latin American Countries

\begin{tabular}{|c|c|c|c|c|c|}
\hline & Mexico & Guatemala & Ecuador & Brazil & Argentina \\
\hline GDP per capita at PPP $^{\#}$ & $17,277^{\mathrm{m}}$ & $7,707^{\mathrm{n}}$ & $11,388^{\circ}$ & $15,359^{\mathrm{p}}$ & $\$ 20,700^{\mathrm{cc}}$ \\
\hline \multirow{2}{*}{$\begin{array}{l}\text { Population below national poverty } \\
\text { lines }\end{array}$} & $50.6^{\mathrm{c}}$ & $59.3^{\mathrm{d}}$ & $22.9^{\mathrm{e}}$ & $8.7^{\mathrm{f}}$ & $30.3^{\mathrm{bb}}$ \\
\hline & 2016 & 2014 & 2016 & 2015 & 2016 \\
\hline \multirow[t]{2}{*}{ Adult literacy rate } & $94.47^{\mathrm{m}}$ & $81.29^{\mathrm{n}}$ & $94.35^{\circ}$ & $91.73^{\mathrm{p}}$ & $98.09^{\mathrm{s}}$ \\
\hline & 2015 & 2014 & 2016 & 2014 & 2015 \\
\hline \multirow{2}{*}{$\begin{array}{l}\text { Total expenditure on health } \\
\text { as } \% \text { of GDP }\end{array}$} & $6.3^{\mathrm{a}}$ & $6.2^{\mathrm{g}}$ & $9.2^{\mathrm{i}}$ & $8.3^{\mathrm{k}}$ & $4.8^{\mathrm{t}}$ \\
\hline & 2014 & 2014 & 2014 & 2014 & 2014 \\
\hline Indigenous population ${ }^{\mathrm{q}}$ & 15.1 & 41.0 & 7.0 & 0.5 & 2.4 \\
\hline \multirow{2}{*}{$\begin{array}{l}\text { Life expectancy at birth (male/ } \\
\text { female) }\end{array}$} & $74 / 80^{\mathrm{a}}$ & $68 / 75^{\mathrm{g}}$ & $74 / 79^{i}$ & $71 / 79^{\mathrm{k}}$ & $73 / 80^{t}$ \\
\hline & 2015 & 2015 & 2015 & 2015 & 2015 \\
\hline \multirow[t]{2}{*}{ Hospital beds (per 10,000) } & $15^{z}$ & $6^{\mathrm{y}}$ & $15^{\mathrm{x}}$ & $22^{\mathrm{w}}$ & $50^{\mathrm{v}}$ \\
\hline & 2015 & 2014 & 2013 & 2014 & 2014 \\
\hline \multirow{2}{*}{$\begin{array}{l}\text { Number of pharmaceutical } \\
\text { personnel* (per } 10,000 \text { people) }\end{array}$} & 0.31 & N/A & 0.53 & 7.19 & $5.04^{\mathrm{w}}$ \\
\hline & 2000 & & $\begin{array}{c}2011 \\
\mathrm{US}=8.87\end{array}$ & 2010 & 2004 \\
\hline Physician density (per 10,000$)^{\mathrm{w}}$ & $\begin{array}{r}22.31 \\
2015\end{array}$ & $\begin{array}{r}8.73 \\
1999\end{array}$ & $\begin{array}{r}16.65 \\
2011\end{array}$ & $\begin{array}{r}18.52 \\
2013\end{array}$ & $\begin{array}{r}39.07 \\
2013\end{array}$ \\
\hline \multirow{2}{*}{$\begin{array}{l}\text { Maternal mortality ratio (per } \\
100,000 \text { live births) }\end{array}$} & $38^{\mathrm{z}}$ & $140^{\mathrm{h}}$ & $87^{j}$ & $69^{1}$ & $52^{\mathrm{u}}$ \\
\hline & 2013 & 2013 & 2013 & 2013 & 2015 \\
\hline \multirow[t]{2}{*}{ Fertility rate (per woman) } & $2.2^{\mathrm{b}}$ & $3.8^{\mathrm{h}}$ & $2.6^{\mathrm{j}}$ & $1.8^{1}$ & $2.2^{\mathrm{aa}}$ \\
\hline & 2013 & 2013 & 2013 & 2013 & 2013 \\
\hline \multirow{2}{*}{$\begin{array}{l}\text { Under five mortality rate (per } 1000 \\
\text { live births) }\end{array}$} & $15^{\mathrm{b}}$ & $31^{\mathrm{h}}$ & $23^{j}$ & $14^{1}$ & $13^{\text {aa }}$ \\
\hline & 2013 & 2013 & 2013 & 2013 & 2013 \\
\hline \multirow[t]{3}{*}{ Most common cause of death } & $\begin{array}{l}\text { diabetes } \\
\text { mellitus }\end{array}$ & $\begin{array}{l}\text { lower respiratory } \\
\text { infections }(12 \%)^{\mathrm{h}}\end{array}$ & $\begin{array}{l}\text { ischemic } \\
\text { heart disease }\end{array}$ & $\begin{array}{l}\text { ischemic } \\
\text { heart disease }\end{array}$ & $\begin{array}{l}\text { ischemic heart } \\
\text { disease }(15.9 \%)^{\text {aa }}\end{array}$ \\
\hline & $(14.5 \%)^{b}$ & & $(10.3 \%)^{\mathrm{j}}$ & $(10.5 \%)^{1}$ & \\
\hline & 2012 & & 2012 & 2012 & \\
\hline
\end{tabular}

\# Gross Domestic Product per capita at Purchasing Power Parity

* Defined as pharmacists, pharmaceutical assistants, pharmaceutical technicians and related occupations

a. http://www.who.int/countries/mex/en/

b. http://www.who.int/gho/countries/mex.pdf

c. https://data.worldbank.org/country/mexico?view = chart

d. https://data.worldbank.org/country/guatemala?view= chart

e. https://data.worldbank.org/country/ecuador?view=chart

f. https://data.worldbank.org/country/brazil

g. http://www.who.int/countries/gtm/en/

h. http://www.who.int/gho/countries/gtm.pdf

i. http://www.who.int/countries/ecu/en/

j. http://www.who.int/gho/countries/ecu.pdf

k. http://www.who.int/countries/bra/en/

1. http://www.who.int/gho/countries/bra.pdf

m. https://en.unesco.org/countries/mexico

n. https://en.unesco.org/countries/guatemala

o. https://en.unesco.org/countries/ecuador

p. https://en.unesco.org/countries/brazil

q. https://repositorio.cepal.org/bitstream/handle/11362/37051/4/S1420782_en.pdf (from United Nations, 2010 data)

r. https://data.worldbank.org/country/Argentina (Poverty Headcount Ratio at National Poverty Lines - \% of Population)

s. https://en.unesco.org/countries/argentina

t. http://www.who.int/countries/arg/en/

u. http://apps.who.int/gho/data/node.country.country-ARG?lang=en

v. http://apps.who.int/gho/data/view.main.HS07v

w. http://apps.who.int/gho/data/view.main.92100

x. http://apps.who.int/gho/data/node.country.country-ECU?lang=en

y. http://apps.who.int/gho/data/node.country.country-GTM?lang=en

z. http://apps.who.int/gho/data/node.country.country-MEX?lang=en

aa. http://www.who.int/gho/countries/arg.pdf

bb. https://data.worldbank.org/country/argentina

cc. https://www.cia.gov/library/publications/the-world-factbook/geos/ar.html 


\section{American Journal of Pharmaceutical Education 2019; 83 (4) Article 7218.}

Brazil has the world's eighth largest economy in terms of gross domestic product (GDP) and purchasing power parity. It has the largest economy in Latin America and the second largest in the Americas after the United States. ${ }^{10,11}$ Major industries include oil, tourism, agriculture, mining, and arms manufacturing. ${ }^{10,11}$ Brazil is also the sixth largest global pharmaceutical market and a popular destination for health tourism, especially for cosmetic surgery. ${ }^{13}$

The federation is divided into five regions containing 26 politically independent states and the federal district of Brasília, and 5,570 municipalities. ${ }^{14}$ The president of the federation is the head of state and head of the government, and is directly elected by the people. $^{15}$

Ecuador. Ecuador is a geographically diverse country with Amazonian jungles, central highlands with the Andes Mountains, a coastal plain, and the Galapagos Islands. ${ }^{16}$ The capital, Quito, is located in the highlands. ${ }^{16}$ The population of Ecuador is approximately 16 million people of which $72 \%$ are Mestizo (mixed Amerindian and white), $7 \%$ are Amerindian, and $4 \%$ are Afroecuadorian. ${ }^{16}$ There are 14 different indigenous groups that are politically represented by the Confederation of the Indigenous Nations of Ecuador. ${ }^{17}$ Spanish and Kichwa (also written as Quechua) are the official languages of Ecuador. ${ }^{18}$ Spanish is spoken by $93 \%$ of the population and other indigenous languages are spoken by approximately 5\%. ${ }^{16}$ In 2016, $22.9 \%$ of the population was living below the poverty line. ${ }^{19}$

Ecuador is governed by a presidential republic through a 137-seat, unicameral National Assembly. ${ }^{16}$ Ecuador is unique in that the official currency has been the US dollar since 2001. The country exports many agricultural goods, including bananas, cocoa, coffee, and flowers. Oil and petroleum products account for more than $50 \%$ of its export income, exposing the country to significant income variations when there are fluctuations in the markets. ${ }^{16}$ There are some mining operations in Ecuador that may expose the population to industrial chemicals. $^{20}$

Guatemala. Guatemala is the most populous country in Central America with over 15 million people. ${ }^{21}$ With the highest fertility rate in Latin America, Guatemala's population continues to rapidly grow. ${ }^{21}$ Two mountain chains divide the country into three regions; a majority of people live in the mountainous south and half of the population lives in rural areas. ${ }^{21}$ Guatemala City is the capital and Guatemalans refer to themselves as Chapin or Chapina, a widely accepted colloquial term.
Guatemala is a multicultural and multilingual country. While Spanish is the official language, $22 \mathrm{Ma}-$ yan languages, and Xinca and Garífuna are spoken in the rural areas, resulting in sociocultural communication challenges. $^{22}$ The population of Guatemala is divided into two main groups: indigenous Mayas and Ladinos or Mestizos, who have a blend of Hispanic and Mayan roots. ${ }^{23}$ Ladinos compromise $60 \%$ of the population, tend to live in more urban areas, and hold more economic and political power than the Maya population. The indigenous populations reside primarily in rural areas and have been impacted to a greater degree by the country's problems with health and development, including infant and maternal mortality and malnutrition. ${ }^{21}$

The World Bank Poverty Assessment indicates that poverty rates decreased from $56 \%$ in 2000 to $51 \%$ in 2006 , but 2014 shows a rise to $59.3 \% .{ }^{24}$ Guatemala's economy depends largely on crops such as sugar, coffee, and bananas, and the government has struggled to promote economic growth. ${ }^{25}$ A positive development has been the formation of The Dominican Republic-Central American Free Trade Agreement (CAFTA-DR) in 2006, which increased ethanol and nontraditional exports, such as flowers. ${ }^{21}$ Despite this change, over half of the country's population lives below the poverty line, and extreme economic disparity exists between indigenous and nonindigenous groups. $^{21}$

The current government is a presidential republic, but Guatemala has scars from a 36-year civil war (19601996) during which an estimated 200,000 people were massacred and approximately one million Maya were forced to leave or chose to flee between 1981 and $1985{ }^{26-30}$ An estimated half a million Maya migrated to the United States since the start of the war. ${ }^{31}$ The political scene is in unrest as multiple political parties have been in power since the end of the Civil War. Corruption has been rampant in the government while several of the nation's presidents and political figures have been jailed or are under investigation. ${ }^{32}$

Mexico. Mexico ranks $11^{\text {th }}$ in world population (127.5 million), with most of its population located in the middle of the country between the states of Jalisco and Veracruz. ${ }^{33}$ The capital of Mexico City, with approximately 20 million people, is home to nearly one sixth of the country's population. ${ }^{33}$ The northern part of Mexico has an arid climate while southern Mexico is tropical. ${ }^{34}$

Based on influences of the physical environment, historical settlement, and ethnicity, Mexico is home to several pueblos indígenas (indigenous civilizations), some of which include the Maya, Huicholes, Mixtecos, 


\section{American Journal of Pharmaceutical Education 2019; 83 (4) Article 7218.}

and Otomíes. ${ }^{35}$ The mixture of indigenous and Spanish heritage, referred to as Mestizo, has resulted in a unique blend of ethnic traditions. This group constitutes the largest segment of the population (62\%), followed by predominantly indigenous people $(21 \%){ }^{33,34}$ Although almost all Mexicans speak Spanish, there are also more than 50 indigenous languages spoken. ${ }^{34}$

Mexico's government is a federal presidential republic that is comprised of 31 states and one city (Mexico City). ${ }^{33}$ Since Mexico and the US share a border, their interdependent relationship affects many facets including the economy, with $\$ 1.7$ billion in two-way trade. ${ }^{36}$ There is a large degree of inequality based on income distribution and poverty in Mexico. In fact, Mexico ranks second in inequality among countries in the Organization for Economic Cooperation and Development $(\mathrm{OECD}){ }^{37}$ Financial inequalities impact health inequities, including differences in living conditions, disease burdens, access to and quality of health care, and health outcomes.

\section{Health Care Systems}

There are several challenges to accessing health care in Latin America, including education, socioeconomics, transportation, and organizational structure. Additionally, cultural barriers can be identified from four areas: the structure or system, the establishment or health space, the personnel providing health services, and the patient population. ${ }^{38}$ Providers should also recognize the reasons patients seek health care services in order to maximize the impact of these interactions.

In many Latin American countries, public health care systems are organized in a hierarchical manner with primary health care at the base from which patients are referred to secondary and tertiary hospitals as needed. Private hospitals are generally better equipped and more sophisticated than public hospitals, but significantly more expensive. Although many Latin American countries have made progress in expanding government-funded insurance coverage, the demand for services is high, and there is a lack of sufficient human and economic resources. Health disparities are also evident between indigenous and nonindigenous populations. $^{39}$

Latin America has been the victim of severe natural disasters that have caused devastating losses in terms of lives and infrastructure. In June 2018, a volcano eruption in Guatemala, and in September 2017, an earthquake in Mexico and Hurricane Maria in the Caribbean Islands affected thousands of residents and required massive rebuilding efforts. The countries faced severe challenges following these natural disasters including poverty, inadequate communication, and lack of infrastructure. ${ }^{40}$ When students and professionals are considering where to travel for a global experience, they need to realize and consider that the devastation from natural disasters may be evident years after the event and can be taxing on the area's health care system.

Argentina. Both public and private hospitals and clinics are distributed throughout Argentina, but access is more difficult in rural areas and in the Andean northwest of the country. ${ }^{8}$ The health care workforce in both public and private hospitals are well trained, and most of them are from outside the country. ${ }^{8}$ The health care system is financed by three groups: the public system, the mutual or social plans, and the private system. ${ }^{41}$ The public system, financed through taxes, provides free inpatient and outpatient medical care and is used mainly by those not working or those working but not members of unions. This sector covers about $50 \%$ of the Argentine population. Approximately 300 mutual or social plans, commonly referred to as the "mutuals" are administered by trade unions, with employees and employers contributing. The mutuals provide coverage for about $45 \%$ of the population, paying for patients' medical and medicine costs according to agreed upon proportions. However, rising unemployment rates have resulted in fewer people covered by this system. The private health care sector covers about $5 \%$ of the population and the full cost of treatment is borne by patients, either out of pocket or paid by insurance. Health plans are also offered to the public by some of the larger private hospitals. ${ }^{8}$

Brazil. The Brazilian constitution of 1988 recognized the Right to Health, as enshrined in the constitution of the WHO, and states that, "Health is a private right and a duty of the state." ${ }^{42}$ Toward fulfilling this constitutional mandate, the Brazilian government established a national public health system, the Sistema Único de Saúde (Unified Health System or SUS), in $1990 .^{43}$ The SUS operates on the three principles of universality, equity, and integrality, and is financed jointly by the federal, state, and municipal governments through taxes. Although health care is a right in Brazil, about $75 \%$ of the population depends entirely on the SUS for their health care needs and the remaining $25 \%$ receive health care from the private sector. Private health care is paid for by employersponsored health insurance or some other private insurance. ${ }^{44}$ However, because the Brazilian constitution guarantees access to health care for all its citizens, those with private health insurance coverage can, at any time, demand health care through the SUS as a matter of right. ${ }^{44}$ This has given rise to what is termed the "judicialization of health." 44 


\section{American Journal of Pharmaceutical Education 2019; 83 (4) Article 7218.}

This term is used to describe the practice where Brazilian citizens with private health insurance coverage frequently take legal action against their government to demand coverage for sophisticated health care technologies and treatments through SUS when these treatments become eligible for coverage in the public sector. The Brazilian government has established the National Network of Technology Assessments in Health to help address this issue, taking into consideration that in 2016 the federal, state, and municipal governments spent a total of $\$ 2.25$ billion handling health-related lawsuits. ${ }^{44}$

Primary health care in the SUS is delivered by a network of 67,000 primary care physicians, 26,000 community health workers, 38,000 primary care units, 6,690 hospitals ( $70 \%$ of which are private contractors), 10,463 public pharmacies, and 79,990 private pharmacies. ${ }^{43}$ Primary health care is organized through two types of units: Unidade Básica de Saúde (Basic Health Units or UBS) and the Family Health Program (Programa Salud de la Familia or PSF), which was established in 1994. A PSF team consists of a family doctor, a nurse, a nursing assistant, and six community health workers. Each team is responsible for the basic health care needs of up to 4,000 community residents. ${ }^{43,44}$ The community health workers, in pairs, pay routine visits to families to meet their basic health care needs, monitor vital signs, provide health education, and see to the general well-being of their assignees. Family Health Support Centers, which house specialists and pharmacists, provide the PSF with the support needed to handle more complex patient cases. ${ }^{43,44}$

The disease burden in Brazil is both communicable (infectious) and noncommunicable, with the latter quickly overtaking the former, particularly with cardiovascular diseases, cancers, and respiratory diseases accounting for $72 \%$ of mortality. ${ }^{45}$ Deaths from infectious diseases declined from $6.2 \%$ in 1990 to $4.5 \%$ in 2011 as a result of improved access to water and sanitation, high pediatric vaccination coverage, and improved environmental and living conditions. ${ }^{45}$ However, there are still significant health disparities in Brazil, with the poorer populations living in the mountainous and river-laden regions of the north and northwest and having poorer health and less access to quality health care personnel and resources than the more affluent populations in the south and southeast.

Ecuador. Ecuador has had 20 constitutions since its formation in $1830 .{ }^{46}$ In the most recent constitution (2008), health was declared a human right and a national health service was established to provide universal and free public health care, including complementary and alternative medicine. ${ }^{18}$ Health services are provided by both the public and private sectors. Within the public sector, the Ministry of Public Health, the Social Security Institute of the Armed Forces, and the Social Security Institute of the National Police offer health care services to the entire population. ${ }^{47}$ The health care system of the Ministry of Economic and Social Inclusion and the municipalities also provide care for the uninsured population.

The Ecuadorian Institute of Social Security provides care to the unemployed and their dependents. In 2016 , there were 4,200 health establishments, with $81 \%$ $(3,422)$ operated by the public sector, $14 \%(603)$ by forprofit organizations, and 4\% (175) by charitable and nongovernmental organizations (NGOs). ${ }^{48}$ The health care system is designed around a model called the Family, Community, and Intercultural Integral Care Model, which is intended to promote wellness and preventative care at the primary care level. ${ }^{18}$ Despite these ambitious goals, the public health sector is inadequate for the health care needs of the population. The result is an oftenfragmented health care system in which many citizens do not have access to high quality care. Health care expenditures as a percentage of the GDP continue to climb, reaching $8.5 \%$ in $2015 .{ }^{49}$ While Ecuador has made great strides in reducing morbidity and mortality, these improvements are not equally distributed across the population. ${ }^{50}$

Guatemala. Guatemala has the largest economy in Central America, but also rates among the highest in economic inequality in Latin America. The health care system has undergone multiple transitions over the past two decades as a result of post-war recovery. Uncertainty remains about how to create a more stabilized, fully financed system. The public health care system is called the Ministry of Public Health and Social Assistance (MSPAS). According to the legal framework, MSPAS must be carried out in the health system and has constitutional obligations to provide health promotion, prevention, healing, rehabilitation, and follow-up services. The MSPAS is made up of 29 Areas de Salud (Health Areas), divided into three levels of health care spanning across urban and rural locations. The health system is nationally complemented by autonomous; semi-autonomous municipal, private, and social service institutions, such as the Guatemalan Social Security Institute (IGSS); Catholic and other church parish clinics; municipal clinics and organizations; NGOs; international government aid; religious and secular medical missions; the Military Hospital; and the National Police Hospital. Health services provided by organizations other than the Guatemalan government are critical considering national health concerns and the low health budget. National Institute of Statistics (INE) data from 2014 revealed that $45 \%$ of the population received health care at MSPAS, $22 \%$ at private 


\section{American Journal of Pharmaceutical Education 2019; 83 (4) Article 7218.}

clinics, $8 \%$ at pharmacies, $7 \%$ at IGSS, and 5\% at other community centers. ${ }^{22}$

In $2014,89.2 \%$ of the population was not covered by health insurance, 9.2\% was affiliated with IGSS for workers in the tax-paying, formal sector of the country's workforce, $1.1 \%$ was covered by private health insurance, and $0.5 \%$ was covered by Sanidad Militar (Military Health). ${ }^{22}$ This situation has created subsequent problems nationally for the MSPAS and represents enormous financial burden to families, many of which live in poverty. Private insurance, which is very uncommon, includes not only for-profit clinics and hospitals, but also not-for-profit organizations, such as NGOs and faith-based organizations. Overall, $52 \%$ of the total health expenditure is from out-of-pocket spending. ${ }^{51}$ Guatemala's health expenditure per capita is $\$ 176$ at Purchasing Power Parity (PPP), the lowest in the region, which averages $\$ 436$. The PPP shows "the ratio of prices in national currencies of the same good or service in different countries." 52 The low budget that is designated for health results in medicine and health care supplies being out of stock and fewer health services being available, particularly in rural areas. ${ }^{51}$

Access to health care is poor because of a shortage in health care workers and major population dispersion in rural areas, especially in southwestern Guatemala. The WHO recommends a ratio of 22.8 health care personnel per 10,000 people. In Guatemala, urban areas have average ratios of $25.7 / 10,000$, while average ratios in rural regions are only $3 / 10,000 .^{51}$ Another consideration is the language fluency of the health care workers. With multiple indigenous languages, challenges may arise if the health care provider only speaks Spanish and not the patient's preferred language.

Guatemala's primary health challenges are maternal and child health, with the highest rates in maternal and child mortality and malnutrition in the hemisphere. There are health disparities among indigenous and nonindigenous women, particularly in rural regions and where Maya reside. ${ }^{51}$ The percent of women who deliver their babies in a health care facility is $30 \%$ for indigenous women and $71 \%$ for nonindigenous women. ${ }^{51}$ Childhood malnutrition, related to food insecurity, has also been a priority for the health care system.

Mexico. The Mexican public health care system provides care to over $95 \%$ of the population through the Mexican Institute of Social Security (IMSS), Institute for Social Security and Services for State Employees (ISSSTE), and Seguro Popular de Salud (Seguro Popular or Popular Insurance) ${ }^{53}$ Other less common types of public insurance exist that are beyond this article's scope. The IMSS, which insures approximately 58 million people, provides benefits to workers in traditional employment positions as well as to the families of workers and retirees. ${ }^{53}$ The ISSSTE covers government employees and provides benefits to 13 million people. ${ }^{53}$ Seguro Popular, which began in 2004, is a publicly subsidized health insurance plan for the unemployed. Although the intention of Seguro Popular is to reduce the gaps in health care inequalities, challenges remain in achieving this goal. According to the 2016 OECD assessment of the Mexican health care system, distinct subsystems, which provide inequitable care, have resulted in serious challenges to effectiveness and efficiency. ${ }^{53}$ Very few Mexicans can afford private insurance. Additionally, out-of-pocket spending is around $45 \%$ of total health spending, the highest in the OECD. ${ }^{53}$

Some of the most common patient complaints when accessing health services regarding attitudes of indifference, dehumanization, depersonalization, and discrimination from medical and nursing professionals. ${ }^{54}$ Patients feel their expectations are not considered by medical staff members. Among vulnerable groups, there is concern that their traditional beliefs and practices about health and illness will be disregarded. ${ }^{54}$

Mexico's most difficult health care challenges are obesity and type 2 diabetes. While the prevalence of overweight and obesity in adults combined is $72.5 \%$, diabetes is the leading cause of death and disability in Mexico. ${ }^{55} \mathrm{In}$ 2016, the health ministry declared diabetes a national health emergency and defined three areas of focus: new public health strategies (such as taxes on sodas), improved access to medical care, and expanded fiscal and regulatory policies. ${ }^{56}$

\section{Pharmacy}

In general, more medications are available without a prescription in Latin American countries than in the United States. Thus, many patients turn to their local pharmacist for advice about self-medication. In many countries, auxiliary staff members play a larger role in advising patients, while professionally trained pharmacists are less available. Complementary and alternative medicine use and practice are popular in Latin America and go side-by-side with allopathic medicine. While there are some examples in Latin America where pharmacists are integrated into the health care team, generally they work in relative isolation and are underutilized because other professionals do not value their contributions as a health care provider. ${ }^{57}$

Argentina. Argentina has four essential lists of medicines that are provided free of charge to patients; any drugs prescribed that are not on one of these lists are paid out of pocket by the patient or by supplemental 


\section{American Journal of Pharmaceutical Education 2019; 83 (4) Article 7218.}

insurance. $^{41}$ In the public health care system, REMEDIAR, the national free drug program, finances, procures, stores, and distributes drugs on its essential list to primary health care centers and public hospitals and centers across the country. The Bureau of AIDS and STDs also provides free antiretroviral drugs and drugs for opportunistic infections on its essential drug list. The drugs on the essential drug list of the trading block MERCOSUR are also candidates for free supply, as needed. Finally, there is an essential drug list for the Compulsory Medical Program (PMO), which caters to the prepaid private sector as well as the mutuals. ${ }^{41}$

There are 18 public and private pharmacy programs in Argentina, all are five-year undergraduate degree programs. ${ }^{58}$ The majority of pharmacists work in community practice, although efforts in education and practice are being made to incorporate more clinical knowledge and skills. ${ }^{59}$ A study in 2008 identified three major barriers to the growth and expansion of pharmaceutical care in the country. Chief among them were lack of time, lack of specific training, and the lack of communication skills. ${ }^{59}$

Brazil. Medicines in Brazil are classified into three groups for financing purposes: basic medicines, strategic medicines (eg, for leprosy, tuberculosis, malaria, and HIV/AIDS) and specialized medicines or high-cost medicines that are used strictly under clinical protocols and guidelines. ${ }^{44}$ The distribution and dispensing of the first two groups are decentralized at the municipal level; only state governments control specialized medicines. Most prescriptions in the SUS are dispensed by public, SUSowned pharmacies. However, through a public-private partnership program called the Popular Pharmacy of Brazil (Farmácia Popular do Brazil), medicines for hypertension, diabetes, and asthma are supplied free of charge. The government covers $90 \%$ of the cost of other medicines. ${ }^{42,44,60}$ Brazil is becoming a large global pharmaceutical market. ${ }^{60}$ However, the medicine supply chain in the SUS system is deficient, fraught with out-of-stock medicines, and inadequate availability of much-needed medicines and hence forcing many patients to purchase their medicines privately and pay out of pocket. ${ }^{61,62}$ Price controls for medicines are enforced in Brazil but not in other countries.

Pharmacy education consists of a four-year Bachelor of Pharmacy degree with a required internship covering a minimum of $20 \%$ of the pharmacy course load. ${ }^{42}$ The over 500 pharmacy schools in the country graduate 18,500 pharmacists annually, $64 \%$ of whom are women. ${ }^{42}$ Private community pharmacies employ $78.8 \%$ of all pharmacists, followed by public pharmacies $(10.3 \%)$ and hospital pharmacies $(6.4 \%) .{ }^{42}$ Although Brazil has an extensive pharmaceutical market, with both government and privately owned local and global industries, only $0.4 \%$ of pharmacists pursue a career in industry. ${ }^{13,42}$

Ecuador. The Agencia de Regulación, Control, y Vigilancia Sanitaria (Agency for Regulation, Control, and Surveillance of Health) is responsible for registration and regulation of medications in Ecuador. ${ }^{63}$ The agency reviews the efficacy, safety, and quality of all drugs that will be marketed in Ecuador. ${ }^{63,64}$ The National Pharmacovigilance Center was established in 2011, but training personnel has been slow. ${ }^{64,65}$ However, an online reporting system is now available. ${ }^{65}$ The Agencia de Regulación, Control, y Vigilancia Sanitaria is charged with assuring medication quality and in 2014, laws were codified to combat counterfeit medications. ${ }^{63}$ Medications are divided into nonprescription medications (13.6\% of all registered medicines) and prescription medications ( $86.4 \%$ of all registered medicines). ${ }^{66}$ Within the prescription group, $14 \%$ fall under the control of the National Council for the Control of Narcotic Substances and Psychotropic medications. However, a 2011 report found that $77 \%$ of patients bought prescription medications without a prescription. ${ }^{66}$ Another study found that approximately $10 \%$ of first-year nursing students obtained benzodiazepines for personal use from pharmacies without prescriptions. ${ }^{67}$ Almost $70 \%$ of dispensed medications are proprietary formulations and represent $93 \%$ of pharmacy sales. ${ }^{66}$ The low number of generic medications used represents potential cost savings to the health care system; however, many health professionals and patients are concerned about the quality of generic medications.

In Ecuador, a single community pharmacist is permitted to supervise two or three pharmacies, as long as he or she is present for at least 20 hours/month in each pharmacy. ${ }^{68}$ Pharmacies are required to be open 12 hours a day, Monday through Friday. The National Agency for Regulation, Control, and Surveillance of Health established a schedule for on-call pharmacies that requires them to provide overnight and weekend coverage. ${ }^{68}$ These regulations leave pharmacies in the hands of pharmacy assistants and technicians for much of the time they are open. These employees are only required to complete secondary school and a special course on handling medications to obtain a permit card that allows them to work in this capacity. ${ }^{68}$ Like other health care resources, $90 \%$ of pharmacies are concentrated in urban areas. ${ }^{66}$

There are six pharmacy schools in Ecuador; however, there is no accrediting body for pharmacy education. ${ }^{69-71}$ The curriculum generally takes students five to six years to complete following completion of their secondary schooling. As part of the academic program, students must complete a thesis and a practice requirement. A government mandated community service experience 


\section{American Journal of Pharmaceutical Education 2019; 83 (4) Article 7218.}

is also required. No national licensure examination is required before starting practice. Graduates work in laboratories, community and hospital pharmacies, industry, and academia. While Ecuador is not a large country, at least four US pharmacy programs had ties to Ecuador in $2013 .^{72}$

Guatemala. In Guatemala, the pharmacy profession is regulated by the Department of Regulation and Control of Pharmaceutical Products and Related Products (DRCPFA). About 10,000 pharmaceutical-related businesses, including product and drug manufacturers, pharmaceutical distributors, and pharmacies, are located in Guatemala. ${ }^{51}$ Pharmaceutical price regulation in the private sector lacks legal or regulatory provisions for fixed pricing of medicines. There is also no active national system for monitoring retail medication prices, and there are no regulations requiring that medication costs be publicly accessible. Therefore, statistical studies on cost of medications are not available. ${ }^{73}$ In the public sector, acquisition is based on supplier prequalification through the GUATECOMPRAS (State Contracting and Procurement Information System) law; however, this system is constantly manipulated for personal benefits. ${ }^{74}$ Furthermore, there is a lack of national guidelines on distribution practices and an authority to license them. These exist only at the level of individual health areas and MSPAS hospitals and not at the private sector. ${ }^{73}$

Pharmacies are divided into two classes, which determine the types of prescriptions that can be purchased there. First-class pharmacies can sell narcotics and psychotropic medications and are staffed, at least part of the time, by a pharmacist. ${ }^{75}$ Second-class pharmacies are run by pharmacy auxiliary staff members and cannot sell narcotics. ${ }^{75}$ Two additional areas where medication can be obtained are at the state hospital pharmacies and at health centers or posts where free generic medicines are provided for the entire population. However, health centers and posts, which provide basic health care and family planning in rural areas, often lack the necessary medications. If a patient has been hospitalized, home visits promoting adherence to therapy are carried out as a way to reduce antifungal and antibacterial resistance. ${ }^{73}$ Publicly funded medicines are offered at no cost for sexually transmitted diseases, immunizations, and family planning. ${ }^{73}$

There are four universities in Guatemala that offer professional pharmacy programs. ${ }^{76-80}$ Most offer a bachelor's degree in pharmaceutical chemistry that takes four to five years to complete. Many pharmacy staff members have not completed a formal, professional training program. $^{81}$

Mexico. Mexico has seen an increase in community pharmacy chains and a decrease in traditional, indepen- dently owned, community pharmacies. Chain pharmacies frequently offer lower prices and a wider range of stock. ${ }^{82}$ The General Health Law in Mexico defines controlled substances as medications such as opioids, tricyclic antidepressants, and antipsychotics. ${ }^{83}$ The State Commission for the Protection of Health Risks, which is the state subdivision of the National Regulatory Agency, inspects pharmacies and verifies implementation of the law. ${ }^{84}$

Only pharmacies that sell controlled substances are required to hire a pharmacist with a Chemist, Pharmacist, Biologist (QFB) degree. ${ }^{85}$ The Mexican Council for the Accreditation of Pharmaceutical Education has approved 32 schools to administer the bachelor's degree program. Seventy-eight percent of these programs confer the QFB degree. ${ }^{86}$ This degree qualifies the graduate to practice in industry, research, and manufacturing. The majority of QFB graduates pursue those fields rather than clinical pharmacy or dispensing roles. The degree requires from 8 to 10 semesters of university education following high school. All Mexican university students are also required to complete hours of service prior to graduation, regardless of their field of study, but the number of hours depends on the degree. For health degrees, a year of service is commonly required. Pharmacy clerks often complete dispensing tasks in community pharmacies. They are unsupervised and do not commonly have educational prerequisites beyond completion of high school. Clerks can be very influential in making drug therapy recommendations. ${ }^{83}$ A study by Kroeger and colleagues reported on inadequate drug advice given by clerks in Mexican pharmacies; staff training, commercial pressures to sell products, and few regulations in clinical practice contribute to this outcome. ${ }^{75}$ Thus, here is an opportunity to expand partnerships between the US and Mexico for pharmacy training and sharing of experiences. The proximity of the two countries makes for a logical global partnership, yet differences in professional training and practice have limited the number of exchanges. A 2013 survey of 20 US colleges and schools of pharmacy with global programs found that only two had programs in Mexico. ${ }^{72}$

\section{Recommendations for Culturally Sensitive Engage- ment for Pharmacy and Other Health Care Profes- sionals}

Starting a Clinical Relationship. Despite significant cultural and linguistic diversity within Latin America, researchers studying these populations in the context of behavioral health have identified commonalities. A clinician seeking to begin a positive and effective relationship with a patient in this region should consider the concepts of personalismo, simpatía, and amabilidad. Personalismo describes a value of individualism based on internal 


\section{American Journal of Pharmaceutical Education 2019; 83 (4) Article 7218.}

characteristics rather than on achievement as is often seen in the United States. ${ }^{87}$ Simpatia denotes facility with relationships, avoidance of conflict, and graciousness that is highly valued. Both concepts are tied up with amabilidad (amiability or kindness). A clinician may find that a relational style that integrates these concepts and favors interpersonal warmth and politeness, use of small talk, and genial self-disclosure will facilitate good rapport and trust with patients.

Also important are the constructs of dignidad and respeto. Dignidad refers to a high value placed on personal dignity, and respeto to a system of hierarchical respect, where elders (particularly parents and grandparents) are owed respectful deference by younger people. ${ }^{88}$ According to Falicov, in the context of talking about Latino workers and their employers, "There is nothing more meaningful to a Latino than to be treated with dignity, because it grants worth and respect, regardless of position or status achieved in the social or economic hierarchy." 88 Given the power differential granted by nationality, education, and possibly race between a Latin American patient and a health care worker from outside the region, these concepts could be useful to keep in mind, particularly when navigating health care conversations on sensitive topics that could potentially be viewed by patients as embarrassing or shameful.

Communication. There are important linguistic and cultural communication factors to recognize in delivering practice recommendations and in providing effective patient care and counseling. While Spanish is the official language in most of Latin America, there are Latin Americans, particularly indigenous residents, who do not speak Spanish or have limited knowledge of the language. Latinos respect health care providers and may view them as authority figures. In addition to respecting authority figures, patients valuing simpatia may agree to treatment plans too readily, without fully understanding the implications, in order to avoid conflict. Therefore, visiting providers should ensure the patient has an understanding of and commitment to a treatment plan, and time to consider the provider's recommendations. This will help foster interpersonal relationships that are critical for building trust between patients and health care providers. Additionally, social stratification can be extensive between the following groups: urban dwellers and individuals from certain subgroups such as rural or indigenous populations, those with and those without power, and women and men. ${ }^{89}$

Clinically Challenging and Useful Constructs. Once a clinical relationship is established, a health care worker might find other Latin American constructs to be challenging; those same constructs, however, can be reframed and used for effective patient-health care pro- vider relationships. Among Latin Americans, these can include the gender constructs of machismo/marianismo. Machismo can be understood as a definition of manhood that values dominance, virility, and physical courage. A man exemplifying machismo who is a husband and father would be seen as the authority and decision-maker in his family. He may display masculine pride and a patriarchal condescension toward women, but at the same time feel a deep sense of obligation to protect and provide for his family. ${ }^{90}$ Marianismo is a construct of femininity that prioritizes the role of a nurturing wife and mother, religious piety, sexual purity and fidelity, and self-sacrifice for the sake of the family. ${ }^{88}$ These constructs have long been of interest in social science literature, and in recent years, Latin American men and women have become more critical of the behaviors associated with more extreme forms of machismo and marianismo. Nevertheless, these patterns remain and family systems reinforce them. ${ }^{88}$

If understood well, these constructs can actually be used to create more effective patient-practitioner relationships. Health care practitioners can appeal to the family patriarch to ensure his family's well-being by making extra efforts to help them keep their medical appointments and procure treatment. Likewise, although marianismo can limit and damage the boundaries of femininity, its definition of women as precious and indispensable can be helpful in getting a family to coalesce around a female relative to support her medical care. The value of selfsacrifice implicit in marianismo can be used to reframe the effort and discomfort of pursuing diagnosis or treatment: a mother, sister, or daughter may persist in her nurturing role, even if it means caring for her own health in ways that she finds inconvenient or awkward.

Latin American patients may also demonstrate a perspective of fatalism. Fatalism occurs when an individual has an external locus of control, including spiritual beliefs that limit individual power over one's own life. ${ }^{90}$ Latin American patients exhibiting a fatalistic perspective might signal this by using words such as aguantar (to bear it), sobreponerse (to get over it), or controlarse (to control oneself), in other words, repressing what would be regarded by a health care provider as excessive distress. Clinicians should bear in mind that their patients are not simply being obstinate or pessimistic, but this approach to difficulties is an effective coping strategy in the face of oppression and forces outside their control. When working with patients who seem unable to adhere to treatment because of a fatalistic attitude, it may be helpful for clinicians to reframe treatment as the difficulty the patient must endure instead of the illness. In this way a clinician may encourage the patient to adhere to treatment without challenging their perspective. ${ }^{91}$ 


\section{American Journal of Pharmaceutical Education 2019; 83 (4) Article 7218.}

Awareness of Context and Group Names. Despite the vast diversity within Latin America, those not familiar with the region tend to view the region as monolithic and its population as homogenous. Visitors should consider the unique sociocultural history and context of each location and make an effort to learn the meanings of group names relevant to each place. For instance, although some people of Latin American heritage living in the United States might refer to themselves using an umbrella term such as Hispanic or Latino, if a visiting health care provider applied those terms to patients in Latin America it would be inappropriate and disregard their national and local identity, which are more likely to be relevant to their self-concept. Nationals of Latin American countries living in the United States might adopt the terms Hispanic or Latino to provide unity for the sake of political power or to cooperate with the expectations of the Caucasian racial majority. ${ }^{87}$ However, Salvadoran nationals living in El Salvador, for example, are most likely to identify themselves as Salvadoran rather than Latino, and recognize the differences between themselves and their Honduran neighbors more readily than their similarities.

Latin American Religions and Perception of Health. Health practices are influenced by religion and folk beliefs. The most frequently held religious affiliation in Latin America is Roman Catholicism, followed by Protestant denominations and other indigenous beliefs. ${ }^{92}$ Because of the high proportion of Roman Catholics in Latin America, adults, particularly older generations, tend to increase religious practices as part of a process known as self-transcendence. This has been associated with beneficial effects on health, such as the reduction of symptoms of depression and successful aging in the elderly. ${ }^{93}$ Most holidays in Latin America center on Christian traditions or important dates in the country's political history. These holidays and celebrations may impact adherence to therapy or dietary recommendations, for example eating sweet bread during King's Day in January or fasting during cuaresma (Lent). ${ }^{94}$

Perceptions of science can impact understanding and acceptance of disease, illness, and medicine. These concepts can also influence preference to seek modern medicine, use traditional practices, or rely on religious beliefs. The National Council of Science and Technology and the National Institute of Statistics and Geography (INEGI) carried out a survey to determine the public perception of science and technology in Mexico. ${ }^{95}$ According to this survey, approximately $54 \%$ expressed that they believe in faith and science in equal measure. Of the 3200 households interviewed, there were more who "trust more in faith or religion" compared to those who "trust more in science." However, 49\% believe that "technological discoveries will sooner or later destroy the planet," indicating that while they perceive science and technological developments as beneficial, they also consider them to be a danger. According to the INEGI survey, only $33.1 \%$ of Mexicans are interested in topics related to science and technology. The rest expressed a lack of interest because they did not understand these issues.

Cultural Health Beliefs. Visiting health care workers should consider that Latin American patients may frame symptoms in a different context than that found in Western medicine. Patients may present with physical health conditions that the patient may perceive as being of spiritual origin based on cultural beliefs. Hence, these beliefs may affect how patients access the health care system and their degree of adherence to allopathic medical treatment. Mal de ojo (evil eye), ataque de nervios or nervios (nervous attack), susto (fright), and empacho (gastrointestinal distress syndrome) are only a few examples of these cultural health beliefs.

Traditional Medicine and Treatment. Latin Americans may seek out folk healers for the treatment of their conditions, alone or in combination with conventional medicine. Folk healing is more common among, but not confined to, those of lower socioeconomic and educational status. It may be practiced with greater secrecy among the educated and wealthier class because of the stigma attached to it. ${ }^{90}$ Folk or traditional healers go by different names in different localities or cultures. Curandero/a (a practitioner of curanderismo) is a widely used term in Latin America for a folk healer with a wide repertoire; in some regions the term shaman is also used. Other folk healers may be called brujos (witch doctors). In Ecuador, a sobador is another type of healer that uses massage.

Traditional medicines and treatments are used throughout Latin America. Belief in culturally bound ailments poses a challenge because it may decrease patient's adherence to medical treatment while increasing the use of alternative remedies such as herbs or other substances. An example of this is the consumption of cloves during pregnancy in Guatemala, which can result in increased abortions and maternal and infant deaths. Appendix 1 provides an example of the wide variety of common health and healing practices in Mexico. ${ }^{54}$

Traditional healers are a prevalent alternative medicine style well documented in nations such as Ecuador and Mexico. Other types of practices may include cleansing, massage, adjustments, pinching, punctures with different types of thorns, and suctions, among others. Traditional procedures are heavily linked to the region in which they are practiced. Healers will commonly treat patients in unconventional offices in their own home, 


\section{American Journal of Pharmaceutical Education 2019; 83 (4) Article 7218.}

adorned with religious imagery, stamping, effigies, and altars. Objects of perceived power, both energetic and magical, include talismans, quartz, water, garlic, onions, statuettes, herbs, lotions, potions, droplets, and ointments, among others. Other traditional rituals or treatments may include the use of cold and moisture through mud or the use of heat through temazcals (steam baths) or cataplasmas (body wraps) to purify the body or cure illness, such as a fever. ${ }^{54}$ The healers practice using colloquial language.

Traditional healers classify illnesses as either "hot" or "cold," and their treatments correspond accordingly. For example, if a patient has a "hot" illness, such as diabetes, they might treat it by taking cold herbs. "Cold" illnesses, such as a headache, may be treated with hot therapy such as drinking mint tea. This practice may impact the degree to which a patient adheres to medication recommendations, such as vitamins or a prescription drug, if they do not align with the patient's "hot" or "cold" model of health. ${ }^{96}$

Given the vast religious, cultural, and social diversity in communities where culture-bound ailments are deeply ingrained, integrative and inclusive health programs should be considered to reduce inequities among community healers and health care providers. Examples of inclusive health models have been initiated in Guatemala, Mexico, and Ecuador where emphasis is placed on including these ailments in the health care system, not as medical diagnoses, but rather as a way of empowering patients with the intention of strengthening physicianpatient relationships. ${ }^{54,97,98}$ Clinicians can approach patients using folk healing with a spirit of collaboration and through a cultural competency framework to improve patient wellbeing and their own understanding of illness. This perspective is likely to improve clinical rapport, which in turn is likely to improve patient adherence with medical advice including other traditional healers, community health workers, or midwives.

\section{Recommendations for Culturallly Sensitive En- gagement When Hosting Students or Faculty From Latin America}

When hosting Latin American visitors, the hosts should be mindful of cultural differences and expectations. Latin America is a diverse region that contains varied cultures. Thus, recommendations for culturally sensitive engagement are not uniform across or even within Latin American countries. Some cultural aspects to consider include differences in greetings, proxemics, and chronemics between people in Latin America and those in other regions of the world. ${ }^{99}$ For example, in the United States, it is common to greet one another with a handshake, whereas it is customary in many Latin American countries to greet one another with a kiss and hug. This is especially true in the work environment, where a kiss on the cheek would likely be viewed as inappropriate in the United States. What is considered a comfortable distance between colleagues or friends also differs between regions. Latin American colleagues may sit or stand closer to each other than their counterparts in the United States. Those not accustomed to a reduced personal space may display discomfort with body language or even move to create distance.

The phrase "mejor tarde que nunca" (better late than never) is a popular saying in Mexico. Time tends to be more fluid in Latin America. Therefore, when hosting visitors, clarity about the need for punctuality for meetings or activities may help prevent delays. ${ }^{99-101}$ In some settings, it may be acceptable to arrive late to social gatherings, a perspective that could present issues, especially if there is an event or a meal planned at a specific time. To avoid scheduling mistakes, hosts should become familiar with meal times in the guests' country prior to creating event agendas or extending meal invitations. Also, working lunches are typically less common in Latin America than in the United States, as Latin Americans may see lunch as an important time to interact socially rather than to work to stay on schedule. Scheduling time for networking and socializing during events may also be important to Latin American guests. These examples demonstrate the importance of personalismo in Latin American culture.

Communication styles also vary within and between Latin American nations. For example, some Latin Americans may avoid disagreeing in order not to offend, not express their discomfort directly, or hesitate to ask for clarification, all clear examples of simpatia. This is particularly common in Maya cultures and could interfere with health outcomes and data collection. Even within languages, there is a more formal way to refer to superiors and elders. For example, in the Spanish language, usted (formal) is used for "you" instead of tu' (informal) to emphasize respect for the person.

\section{CONCLUSION}

Latin America is a culturally rich region of the world with diverse perspectives on health. This article focuses on general themes seen in Latin American lifestyle, culture, and health care, and the reader should realize that each region has distinct subcultures too numerous to be discussed or summarized in a single document. An individual's culture is a complex constellation of factors expanding beyond one's country or region of residence. Socioeconomic and marital status, education level, age, gender, and sexual orientation, as well as the regional 


\section{American Journal of Pharmaceutical Education 2019; 83 (4) Article 7218.}

perceptions of each of these, are a few of the many factors that contribute to cultural identity. Latin Americans may be influenced by many, some, or only a few of the factors discussed in this paper. During cross-cultural engagements, guests and hosts should keep in mind that each person is unique regardless of where he or she is from as this will help them to avoid making assumptions and forming stereotypes about one another. This article is not a checklist to follow or an exhaustive list of all possible cultural dynamics of health or intercultural interactions, but rather a starting point for understanding this region of the world, its people, and health dynamics. Cultural considerations can be patterned after this framework to gain a deeper cultural understanding of additional countries in the region. The framework provided here can serve as a template for exploring other countries in this region of the world.

\section{ACKNOWLEDGMENTS}

Special thanks to Jeanine Abrons (University of Iowa) for her collaboration and input in the planning phase. Thanks also to the following people who provided thoughtful reviews of the paper: Michael Hogue (Samford University), Stephanie Gabela (University de las Américas - Quito, Ecuador), Lisa Brennan (Wingate University), Natalia Angelim Rossa (University of Mississippi), and Carlos Iván Rodríguez González (Guadalajara, Mexico).

\section{REFERENCES}

1. Prescott GM, Vu BN, Alsharif NZ, Prescott WA. Global health education in doctor of pharmacy programs in the United States. Am J Pharm Educ. 2017;81(2):Article 28.

2. Steeb DR, Overman RA, Sleath BL, Joyner PU. Global experiential and didactic education opportunities at US colleges and schools of pharmacy. Am J Pharm Educ. 2016;80(1):Article 7.

3. Alsharif NZ. Purposeful Global Engagement in Pharmacy

Education. Am J Pharm Educ. 2017;81(10):Article 6882.

4. Merson MH, Page KC. The dramatic expansion of university engagement in global health: implications for US policy. Center for Strategic \& International Studies. http://csis.org/files/media/csis/ pubs/090420_merson_dramaticexpansion.pdf. Accessed October 16, 2018.

5. World Atlas. https://www.worldatlas.com/articles/whichcountries-make-up-latin-america.html. Accessed October 16, 2018 6. Alsharif NA, Khanfar NM, Brennan LF, et al. Cultural sensitivity in global engagement in the Arab World. Am J Pharm Educ. 2019;83(4):Article 7228.

7. One World Nations Online. Argentina. http://www.nationsonline.org/ oneworld/argentina.htm. Accessed October 16, 2018.

8. Just Landed, Argentina. https://www.justlanded.com/english/ Argentina/Argentina-Guide/Health/Health care. Accessed October 16, 2018.

9. Nations Encyclopedia Argentina-Government. http:// www.nationsencyclopedia.com/Americas/Argentinagovernment.html. Accessed October 16, 2018.

10. BrazilGovNews. Brazil in Numbers. http://www.brazilgovnews. gov.br/welcome-to-brazil/fact-sheet. Accessed October 16, 2018.
11. The Central Intelligence Agency. The World Factbook. South America: Brazil. https://www.cia.gov/library/publications/the-worldfactbook/geos/br.html. Accessed October 16, 2018.

12. Instituto Brasileiro de Geografia e Estatística. Censo 2010. https://ww2.ibge.gov.br/english/estatistica/populacao/censo2010/ calendario.shtm. Accessed October 16, 2018.

13. Pharma Boardroom Health Care Life Sciences and Review: Brazil March 2018. https://pharmaboardroom.com/

pharmaboardroom-releases-health care-and-life-sciences-reviewbrazil-2018/. Accessed October 16, 2018.

14. Indicadores e Dados Básicos, Brasília (Brazil): Ministério da Saúde, Datasus; 2012. http://tabnet.datasus.gov.br/cgi/idb2012/ matriz.htm. Accessed October 18, 2018.

15. BrazilGovNews. How the structure of the Brazilian state works. http://www.brazilgovnews.gov.br/federal-government/statestructure. Accessed October 18, 2018.

16. Central Intelligence Agency. The World Factbook: Ecuador. https://www.cia.gov/library/publications/the-world-factbook/geos/ ec.html. Accessed October 16, 2018.

17. United Nations High Commission for Refugees. World Directory of Minorities and Indigenous Peoples - Ecuador. www.refworld.org/ docid/4954ce3223.html. Accessed October 16, 2018.

18. Constitution of the Republic of Ecuador. National Assembly. http://pdba.georgetown.edu/Constitutions/Ecuador/english08.html. Accessed October 16, 2018.

19. The World Bank. The World Bank in Ecuador. https:// data.worldbank.org/country/ecuador. Accessed October 16, 2018. 20. González-Merizalde MV, Menezes-Filho JA, Cruz-Erazo CT, et al. Manganese and mercury levels in water, sediments, and children living near gold-mining areas of the Nangaritza River basin, Ecuadorian Amazon. Arch Environ Contam Toxicol. 2016;71:171182.

21. Central Intelligence Agency. The World Factbook: Guatemala. https://www.cia.gov/library/publications/the-world-factbook/geos/ gt.html. Accessed October 16, 2018.

22. Narciso R. Encuesta Nacional de Condiciones de Vida ENCOVI,Instituto Nacional de Estadística de Guatemala. 2014; tomo 1. https://www.ine.gob.gt/index.php/estadisticas/publicaciones. Accessed October 16, 2018.

23. Söchtig J, Álvarez-Iglesias V, Mosquera-Miguel A, Gelabert-Besada M, Gómez-Carballa A, Salas A. Genomic insights on the ethno-history of the Maya and the "Ladinos" from Guatemala. BMC Genomics. 2015;16(1):131. doi:10.1186/ s12864-015-1339-1.

24. The World Bank in Guatemala. http://www.worldbank.org/en/ country/guatemala/overview. Accessed October 16, 2018.

25. Encyclopedia Britannica. Guatemala. https://

www.britannica.com/place/Guatemala/Political-process\#ref40939.

Accessed October 16, 2018

26. Menchú R, Burgos-Debray E. I. Rigoberta Menchú: An Indian Woman in Guatemala. London: Verso; 1984.

27. Sanford V. Buried Secrets: Truth and Human Rights in

Guatemala. New York: Palgrave MacMillan; 2003.

28. Kobrak P. Huehuetenango: Historia De Una Guerra. Huehuetenango, Guatemala: CEDFOG; 2003.

29. Casaús AM. Guatemala: linaje y racismo. Guatemala, Guatemala: F\&G Editores; 2007.

30. Restall M, Florine GL Asselbergs. Invading Guatemala: Spanish, Nahua, and Maya Accounts of the Conquest Wars. Latin American originals, 2. University Park, Pa: Pennsylvania State UP; 2007. 


\section{American Journal of Pharmaceutical Education 2019; 83 (4) Article 7218.}

31. Loucky J, Moors MM. The Maya Diaspora: Guatemalan Roots, New American Lives. Philadelphia, Penn.: Temple University Press; 2000.

32. Ahmed A, Malkin E. Constitutional standoff pushes Guatemala toward authoritarianism. The New York Times. September10, 2018. https://www.nytimes.com/2018/09/10/world/americas/guatemalacorruption-cicig.html. Accessed October 16, 2018.

33. Central Intelligence Agency. The World Factbook: Mexico. https://www.cia.gov/library/publications/the-world-factbook/geos/ mx.html. Accessed October 16, 2018.

34. Encyclopedia Britannica. Mexico. https://www.britannica.com/ place/Mexico. Accessed October 16, 2018

35. Comisión Nacional para el Desarrollo de los Pueblos Indígenas. https://www.gob.mx/cdi. Accessed October 16, 2018.

36. United States Department of State. U.S. Relations with Mexico. https://www.state.gov/r/pa/ei/bgn/35749.htm. Accessed October 16, 2018.

37. OECD. Inequality and Income. http://www.oecd.org/social/ inequality.htm. Accessed October 16, 2018.

38. The Economist Intelligence Unit. Access to health care in Latin America.http://accesstohealth care.eiu.com/wp-content/uploads/ sites/42/2017/06/Accesstohealth careinLatinAmerica.pdf. Accessed October 7, 2018.

39. World Economic Forum. These are the 5 health challenges facing Latin America. https://www.weforum.org/agenda/2016/06/these-are-the5-health-challenges-facing-latin-america/. Accessed October 17, 2018. 40. Stillwell HD. Natural hazards and disasters in Latin America. Nat Hazards. 1992; 6(2):131-159.

41. Argentina Ministry of Health \& WHO. Argentina:

Pharmaceutical Country Profile. http://apps.who.int/medicinedocs/ documents/s19736en/s19736en.pdf. Accessed October 16, 2018. 42. Melo AC, Galato D, Maniero HK, et al. Pharmacy in Brazil: progress and challenges on the road to expanding clinical practice. CJHP. 2017;70(5):381-390.

43. Paim J, Travassos C, Almeida C, Bahia L, Macinko J. The Brazilian health system: history, advances, and challenges. Lancet. 2011;377(9779):1778-1797.

44. Costa KS, Tavares NUL, Nascimento JM, et al. Pharmaceutical services in primary health care: Interfederative agreement in the development of pharmaceutical policies in the Brazilian Unified Health System (SUS). Rev Saude Publica. 2017;51 Suppl 2:2s. 45. Indicadores e Dados Básicos, Brasília (Brazil): Ministério da Saúde, Datasus; 2012. http://tabnet.datasus.gov.br/cgi/idb2012/ matriz.htm. Accessed October 16, 2018.

46. The World Factbook: Ecuador. https://www.cia.gov/library/ publications/the-world-factbook/geos/print_ec.html. Accessed October 16, 2018.

47. Hospitales de la Policía y FF.AA. se unirán a la gratuidad de la salud pública. El Comercio. December 28, 2009. http://

www.elcomercio.com/actualidad/hospitales-policia-y-ff-aa.html. Accessed October 16, 2018.

48. Registro Estadístico de Recursos y Actividades de Salud. 2016, Instituto Nacional de Estadística y Censos. http://

www.ecuadorencifras.gob.ec/actividades-y-recursos-de-salud/. Accessed October 16, 2018.

49. World Health Organization. Global Health Observatory Data Repository. apps.who.in/gho/data/node.main.A1444. Accessed October 16, 2018.

50. Pan WKY, Erlien C, Bilsborrow RE. Morbidity and mortality disparities among colonists and indigenous populations in the Ecuadorian Amazon. Soc Sci Med. 2010;70:401.
51. Avila C, Bright R, Gutierrez J, et al. Guatemala Health System Assessment. August 2015. Bethesda, MD: Health Finance \& Governance Project, Abt Associates Inc.

52. Purchasing Power Parities. Organisation for Economic Cooperation and Development. https://data.oecd.org/conversion/ purchasing-power-parities-ppp.htm. Accessed October 16, 2018. 53. OECD Reviews of Health Systems: Mexico 2016. OECD, OECD Publishing, Paris. http://dx.doi.org/10.1787/9789264230491-en. Accessed on October 16, 2018.

54. Interculturalidad en Salud, Experiencias y aportes para el fortalecimiento de los servicios de salud. http://www.dged.salud.gob.mx/ contenidos/dged/descargas/docs/InterculturalidadSalud.pdf. Accessed October 16, 2018.

55. Instituto Nacional de Salud Pública.Encuesta Nacional de Salud y Nutrición de Medio Camino 2016. https://www.insp.mx/ produccion-editorial/novedades-editoriales/4669-encuesta-nacionalsalud.html. Accessed October 16, 2018.

56. World Health Organization. Quality of care is key to tackling Mexico's diabetes emergency. Bull World Health Organ. 2017;95:393-394. doi: http://dx.doi.org/10.2471/BLT.17.020617. 57. Alvarez-Risco A, Del-Auila-Arcentales S. Pharmaceutical care in Latin America. In: Alves da Costa F, Foppe van Mil JW, AlvarezRisco A, eds. The Pharmacist Guide to Implementing Pharmaceutical Care. $1^{\text {st }}$ edition. Heidelberg, Germany: Springer International Publishing AG; 2019.

58. Study in Argentina. Universities-Biochemistry and Pharmacy Programs in Argentina. http://studyargentina.com/program/ biochemistry-and-pharmacy.html. Accessed October 16, 2018. 59. Uema SAN, Vega E, Armando PD, Fontana D. Barriers to pharmaceutical care in Argentina. Pharm World Sci. 2008; 30(3):211-215.

60. Yamauti SM, Barberato-Filho S, Lopez LC. The list of drugs in the Popular Pharmacy Program and the Brazilian National Pharmaceutical Care Policy. Cad Saude Publica 2015;31(8):16481662.

61. Nascimento RCRMD, Álvares J, Guerra AA Junior, et al. Availability of essential medicines in primary health care of the Brazilian Unified Health System. Rev Saude Publica 2017;51 (Suppl 2):105.

62. Fiqueiredo TA, Schramm JMA, Pepe VLE. The public production of medicines compared to the National Policy of Medicines and the burden of disease in Brazil. Cad Saude Publica 2017;33(9)e00179815.

63. Agencia Nacionalde Regulación, Control y Vigilancia Sanitaria. http://www.controlsanitario.gob.ec/. Accessed October 16, 2018. 64. Durán CE, Lucio R, Rovira J. Pharmaceutical policy in Ecuador. In Babar ZUD, ed. Pharmaceutical policy in countries with developing health care systems. Adis: Cham, Switzerland. 2017: 221236.

65. Sistema Nacional de Farmacovigilancia. http:// www.controlsanitario.gob.ec/sistemafarmacovigilancia/. Accessed October 16, 2018.

66. Ortiz-Prado E, Galarza C, León FC, Ponce J. Acceso a medicamentos y situación del mercado farmacéutico en Ecuador. Rev Panam Salud Publica. 2014;36:57-62.

67. Parades NP, Miasso AI, Tirapelli CR. Consumption of benzodiazepines without prescription among first-year nursing students at the University of Guayaquil, School of Nursing, Ecuador. Review Latino-am Enfermagem 2008;16:634-639.

68. Ministra de Salud Pública.Reglamento de control y funcionamiento de los establecimientos farmacéuticos: 2012. 


\section{American Journal of Pharmaceutical Education 2019; 83 (4) Article 7218.}

http://www.controlsanitario.gob.ec/wp-content/uploads/downloads/ 2013/11/ESTABLECIMIENTOS-FARMACEUTICOS.pdf.

Accessed October 16, 2018.

69. International Pharmaceutical Federation (FIP). Official World List of Pharmacy Schools. http://academic_institutional_membership.fip.org/ world-list-of-pharmacy-schools/?region $=\&$ country $=$ Ecuador $\&$ show $=$ ALL. Accessed October 4, 2018.

70. Universidad Católica de Cuenca. Carrera de Bioquímica y Farmacia. https://www.ucacue.edu.ec/pregrado/unidad-academicasalud-bienestar/carrera-de-bioquimica-y-farmacia/. Accessed October 4, 2018.

71. Escuela Superior Politécnica de Chimborazo. Escuela de Bioquímica y Farmacia. https://www.espoch.edu.ec/index.php/ component/k2/item/1313.html. Accessed October 4, 2018. 72. Cisneros RM, Jawaid, SP, Kendall DA, et al. International practice experiences in pharmacy education. Am J Pharm Educ. 2013;77(9):Article 188.

73. MSPAS, OPS/OMS. Perfil farmacéutico de la República de Guatemala. Marzo 2012. Apartado 7, 33-39.

74. Sistema de Informactión de Contrataciones y Adquisiciones del Estado. Guatecompras.gt. www.guatecompras.gt. Accessed October 16, 2018.

75. Kroeger A, Ochoa H, Arana B, et al. Inadequate drug advice in the pharmacies of Guatemala and Mexico: the scale of the problem and explanatory factors. Ann Trop Med Parasitol; 2001; 95(6): 60516. doi: 10.1080/00034980120092543.

76. Universidad de San Carlos de Guatemala. https://

www.usac.edu.gt. Accessed on October 16, 2018.

77. Universidad Mariano Gálvez de Guatemala. https://

www.umg.edu.gt. Accessed October 16, 2018.

78. Galileo Universidad. https://www.galileo.edu. Accessed October 16, 2018.

79. Universidad de Valle De Guatemala. http://www.uvg.edu.gt. Accessed October 16, 2018.

80. Perfil Farmacéutico de la republica de Guatemala: 2012. http:// webcache.googleusercontent.com/search?

$\mathrm{q}=$ cache:fqdCytV_0pkJ:www.who.int/medicines/areas/coordination/ pscp_guatemala_sp.pdf $+\& c d=1 \& h l=e n \& c t=c \operatorname{lnk} \& g l=u s$. Accessed October 16, 2018.

81. Flood D, Mathieu I, Chary A, García P, Rohloff P. Perceptions and utilization of generic medicines in Guatemala: a mixed-methods study with physicians and pharmacy staff. BMC Health Serv Res.

2017; 17:27

82. Wirtz V. Organization and operation of the Mexican pharmacies. In: Homedes N, Ugalde A, editors. Pharmacies, pharmacists and the appropriate use of pharmaceuticals in Latin America. Buenos Aires: Editorial Lugar;59-82.
83. Homedes N, Ugalde A. Mexican pharmacies: benefits and risks for border residents in the United States of America and Mexico. Rev Panam Salud Publica. 2013;33(3):196-204.

84. Comisión Federal para la Protección contra Riesgos Sanitarios. Medicamentos y Vacunas. https://www.gob.mx/cofepris/acciones-yprogramas/medicamentos. Accessed October 16, 2018.

85. Dreser A. Mexican pharmacies: regulation and policies. In: Homedes N, Ugalde A, eds. Pharmacies, pharmacists and the appropriate use of pharmaceuticals in Latin America. Buenos Aires: Editorial Lugar; 2011.27-57.

86. El Consejo Mexicano para la Acreditación de la Educación Farmacéutica, A.C. http://www.comaefac.org.mx. Accessed October 16, 2018.

87. McGoldrick M, Giordano J, Garcia-Preto N, eds. Ethnicity and Family Therapy. 3rd ed. New York, NY; Guilford press; 2005.

88. Falicov CJ. Latino Families in Therapy. 2nd ed. New York, NY: Guilford Press; 2014.

89. Beals R. Social Stratification in Latin America. American Journal of Sociology, 1953. 58:327-339.

90. Falicov CJ. Latino Families in Therapy: A Guide To Multicultural Practice. New York, NY: Guilford Press; 1998.

91. Martin-Baro I. Writings For a Liberation Psychology. Cambridge, MA; Harvard University Press; 1994.

92. Religion in Latin America. http://www.pewforum.org/2014/11/ 13/religion-in-latin-america/. Accessed October 16, 2018.

93. Guerrero RF, Lara R. Nivel de Autotrascendencia en un grupo de adultos mayores mexicanos. Rev Cuid. 2017;8(1):1476-87.

94. Guarnero PA. Mexicans. In: Lipson JG, Dibble SL, eds. Culture and Clinical Care. San Francisco, CA: UCSF Nursing Press; 2005. 95. Instituto Nacional de Estadística y Geografía.-México. Encuesta sobre la Percepción Pública de la Ciencia y la Tecnología en México 2011 : ENPECYT /: INEGI, c2013. http://www.beta.inegi.org.mx/ temas/religion/. Accessed on October 16, 2018.

96. Juckett G. Caring for Latino patients. Am Fam Physician. 2013;87(1):48-54.

97. Instituto de Salud Incluyente, El Modelo Incluyente en Salud. http://www.mspas.gob.gt/images/files/modeloincluyente/ ModeloIncluyenteSalud.pdf. Accessed October 16, 2018. 98. Ministerio de Salud Pública, Manual del Modelo de Atención Integral de Salud - MAIS. http://instituciones.msp.gob.ec/ somossalud/images/documentos/guia/Manual_MAISMSP12.12.12.pdf. Accessed October 16, 2018.

99. Morrison T, Conaway WA. Kiss. Bow or Shake Hands: Latin America. Avon, MA: Adams Media; 2007.

100. Juniu S. The impact of immigration: Leisure experience in the lives of South American immigrants. J Leis Res. 2000;32(3):358-381. 101. Understanding transcultural nursing. Nursing. 2005;35:14-23. 


\section{American Journal of Pharmaceutical Education 2019; 83 (4) Article 7218.}

Appendix 1. Examples of Health and Healing Practices ${ }^{54}$

Western alternative and allopathic medicine: Biological chemical therapy (Homeopathy, aromatherapy, cell therapy, enzyme therapy), Movement and manipulation of the body (Chiropractic, osteopathy, chiropractic, Swedish massage, equine therapy), Mind-Body (Family constellations, biofeedback, music therapy), Mind-Mind (cognitive therapy), Biocampo-energy (Bioresonance, magnetotherapy, phototherapy), and Diagnosis (iridology)

Chinese traditional medicine: Acupuncture stimulation (reflexotherapy, auriculotherapy), Energy (Reiki), Balance with the environment-Energy (Feng Shui)

Ayurvedic medicine: Food (Naturism, Detoxification), Movement and manipulation of the body (Yoga, purifying massage and lymphatic drainage), Mind-Body (meditation), Energy (Chakra Alignment, Crystal Therapy)

Greek Hippocratic Medicine: Naturopathy 